\title{
The Comparison of Education System in Australia and Indonesia
}

\section{Sri Marmoah ${ }^{1^{*}}$, Roslinawati Roslan ${ }^{2}$, Miratu Chaeroh ${ }^{3}$, Mutiara Dana Elita ${ }^{4}$ Muna Fauziah ${ }^{5}$}

${ }^{1,3,4}$ Faculty of Teacher Training and Education, Universitas Sebelas Maret, Surakarta, Indonesia

${ }^{2}$ Sultan Hassanal Bolkiah Institute of Education, Universiti Brunei Darussalam, Brunei Darussalam

${ }^{5}$ Faculty of Tarbiyah, Institut Agama Islam Nahdlatul Ulama Kebumen, Kebumen, Indonesia

*e-mail: marmuah@staff.uns.ac.id1 ${ }^{1}$, Roslinawati.roslan@ubd.edu.bn², miratuchaeroh95@gmail.com³ danamutiaradana@yahoo.com ${ }^{4}$, munafauziah6@gmail.com ${ }^{5}$

\begin{abstract}
The education system is a method for directing the educational process. All aspects of learning must be regulated by the educational system. Because each country has a unique system, it is necessary to compare the education system in Indonesia to that of other countries in order to assess and evaluate it. This paper aims to explain and analyze differences in educational systems; and comparing the basic education curricula in Indonesia and Australia. This research is conceptual. Data collection methods are books, the internet, and journals. The study analysis was carried out by collecting and analyzing information about the education system in Indonesia and Australia. The results of the study show that: (1) Australia requires children to study for 10 years, while in Indonesia for 12 years, Australia holds a NAPLAN test and Indonesia holds a NE, and teacher qualifications must be undergraduate in Australia and Indonesia; (2) differences in the education system, among others, the level of material difficulty, assessment, rewards, learning atmosphere, teaching staff, education staff, and religious subjects; and (3) the curriculum in Indonesia has a relationship between education, customs, arts, and religions, meanwhile, the Australian curriculum is designed to support students to be successful, active, well-off and knowledgeable.
\end{abstract}

Keywords: Curricula, Educational Systems, Indonesia, Australia

\section{Introduction}

Today, Indonesia is faced with various internal and external problems in the state. These problems occur as a result of many changes in various fields. One example is the advancement of knowledge and technology so that the result is a shift in socio-cultural values in society. Education as a dynamic institution also feels the impact of the progress and development of education. Education is needed by humans to develop. Quality humans who can compete can be created through good education (Sarica \& Cavus, 2009). The quality of learning, which is still far from being perfect, makes human resource development efforts slow (Charron et al., 2013). The quality of education in Indonesia is expected to be able to answer the demands of the times.

Over the past 20 years, increasing globalization has focused on comparative international education and how different countries are approaching similar education problems (Adha, Gordisona, Ulfatin, \& Supriyanto, 2019). Many educators and education systems today care to equip their students with the knowledge, skills, work habits, and characteristics that have come to be known as 21st-century skills (Sulistiyarini \& Sabirin, 2020; van Laar, van Deursen, van Dijk, \& de Haan, 2017). These include critical, problem-solving, creative, and innovative traits, research and data analysis and synthesis; leadership and teamwork; the ability to deal with diversity; useful oral, written, and visual communication; and self-management and emotional intelligence (Chalkiadaki, 2018). Therefore, teachers need to design competent learning. This design is expected to facilitate students to develop and empower students so that students become responsible, innovative, actively participate in the community environment, and are creative in developing for the nation and the State (Rahim \& Malik, 2015).

\section{${ }^{*}$ Corresponding author.}

Received April 10, 2021; Accepted June 20, 2021; Available online December 25, 2021

This is an open access article under the CC BY-SA license. Copyright $(2021$ by Author. Published by Universitas Pendidikan Ganesha 
Learning is neatly wrapped in curriculum form. The curriculum is an educational design that has a strategic position in all educational activities (Sarkadi \& Alghozali, 2020). Many people consider the curriculum to be a "rail" that determines where education is going so that the basic concepts of curriculum policies need to be studied and understood more deeply. The curriculum is defined as a way to find out aspects of the education system in Indonesia. Assessment of the curriculum contains the advantages and disadvantages of the curriculum set in a country.

The broader scope of the curriculum is the education system used by a country. Through this educational system, a nation can maintain and maintain noble values and their advantages from generation to generation (Muth'im, 2014; Silalahi \& Yuwono, 2018). In line with the growth of social sciences in the 21st century which in its rapid development then focused its attention on the recognition of the dynamic relationship between education and a particular society or country (Wrahatnolo \& Munoto, 2018). Education is seen as a reflection of a society or nation, and vice versa, a society or nation is formed by its education system.

The education system in Australia is ranked 15th out of 78 countries worldwide. This refers to the results of the test held by the Organization for Economic Cooperation \& Development (OECD) in 2015, namely the PISA (Program for International Student Assessment) test in Australia which scored 503 (ranked 15) from an average score of 489 seen from science, reading, and mathematics. In this test, Indonesia is ranked 70th with a score of 396 out of the 78 countries that participated in the program (OECD, 2016).

Now, the education system in Indonesia is not sufficiently able to provide opportunities for its population to work easily, and the needs of students are not yet fulfilled properly. The central government also has not provided satisfaction for its workers while in the company. This gap has an impact on the performance of company institutions/organizations. The education system should provide the skills to equip students for globalization. The teacher's recognition noted that the industry and business world were not satisfied with the implementation of the available education standards because the system had not provided broad skills education to students (Wrahatnolo \& Munoto, 2018). Indonesia is also facing an education crisis, the lack of quality of education, unequal access to education, unclear educational autonomy, and slow improvements in educational facilities (Aziz, 2011). Worse, there is a decrease in the skills of the teacher learning process. Besides, there are constraints of at least the division of time in the curriculum, as well as the strictness and cruelty of the imposition of an authoritarian impression. The system implies that students are only taught to read and count and that is the most complicated obstacle for teachers to teach 21 st-century skills.

Seeing the conditions above, it is even more interesting to study the comparison of the education curriculum in Indonesia with Australia. The comparative study is a scientific discipline that studies educational systems both within one country and between countries (Pfeffer, 2015; Reynolds et al., 2015). Various educational innovations either through exploring creative sources from within the country or through comparative analysis of education from other countries are considered successful in developing the quality of education. Through comparative education analysis, we can find out how other countries plan the development and improvement of their education systems that can be emulated. Comparative education seeks to contribute and make recommendations to policymaking in the context of building and advancing the education system.

In this study, the education system in Australia is used as a comparison because it has several similarities, especially in the perspective of subjects, main ideas, and aspects of skills at each level of education, but the difference lies in the achievement assessment at each level of the curriculum (Michie, 2019). The novelty in this study compared to previous studies lies in the comparison of the overall (comprehensive) aspects of the education system between the education system in Indonesia and the Australian Curriculum. This study aims to representing the education system in Indonesia and Australia; analyzing the differences in education systems in Indonesia and Australia; and comparing the basic education curricula in Indonesia and Australia. 


\section{Method}

This article is conceptual. Conceptual articles are interpreted as a result of an analysis of the thoughts of an existing event/problem (Lasmawan \& Budiarta, 2020). The research results were taken from studies and library materials related to the research topic. The method of collecting data and sources related to the research topic is also known as a literature review. The literature review can be taken from various sources, namely magazines, newspapers, the internet, journals, documentation books, and libraries. The library materials obtained are materials that support or reject the results of the thoughts that the author is reviewing. However, the supporting material for the conceptual article is in the form of previous findings or books. Comparative education analysis is carried out using literature study in exploring the topics discussed. Conceptual articles not only discuss some results from previous articles but also link the writer's critical thinking.

\section{Result and Discussion}

\section{Results Australian Education Systems}

Each State and Territory has laws and regulations regarding curriculum, accreditation of courses, examinations for students, and students' awards. The Australian Government plays a leadership role nationally and works with State and Territory Governments and industry, and communities to improve schools' quality and effectiveness. The Australian Government also provides significant subsidies for public and private schools. In Australia, the school year is from the end of January, or early February, to December. Most States and Territories use a school year system that includes four quarters. Tasmania has a three-quarter school year system. Moreover, there are two broad categories of Australian schools. State schools are mixed directly by the State or Territory Government. Public Schools receive core funding from the State or Territory Government and more funding from the Federal Government. Schools other than public schools receive more funding from the Federal Government, and a large proportion of the funding comes from private donations and school fees. Schools other than Public Schools generally have a particular religious affiliation or style of teaching, and in Australia, many schools other than public schools are catholic schools. Australia has classified its education system into four levels: Elementary School, Middle School, Vocational School, and Higher Education. The length of education for each level varies from state to state. The difference can be observed in Table 1 and Table 2.

Table 1. Classification of Education in the Australian Capital Territory

\begin{tabular}{lcc}
\hline \multicolumn{2}{c}{ Education Level Old Education } & Length of Education \\
\hline Basic Education & Primary School & 6 years \\
Middle Education & Junior Secondary School & 4 years \\
& Senior High School & 2 years \\
\hline
\end{tabular}

Table 2. Classification of Education in other parts of Australia

\begin{tabular}{lcc}
\hline \multicolumn{1}{c}{ Education Level Old Education } & Length of Education \\
\hline Basic Education & Primary School & 7 years \\
Middle Education & Junior Secondary School & 3 years \\
& Senior High School & 2 years \\
\hline
\end{tabular}

Education in Australia requires students to take compulsory education, namely primary education and junior secondary education. So, it is compulsory to study in Australia, which is ten years. Furthermore, students can enter senior high school. The term used for education in Australia is year 1 - 12 (from primary school to high school). At the senior high school level, each student should choose a vocational education program or general education. Vocational education is aimed at the job market, meaning vocational education graduates will be ready to 
work after graduation. Each state has Vocational Education and Training (VET). VET prepares students for work without the need for a bachelor's degree. For students who take general education, they can continue their further education. If the students have taken up university, they will receive the following degrees: bachelor's degree (undergraduate level S1), a master's degree (equivalent to master S2), and Ph.D. (doctoral level).

A trend in all public school systems in Australia since the early 1970s has been the delegation of curriculum responsibility to schools. In some states, curriculum guidelines are centralized, but schools can adapt them to meet local demands and needs. In other states, officials at the center set general objectives, and schools translate them into detailed curricula, but still within the framework of established general goals. A rather significant exception occurs in the secondary school curriculum for the latter grades. Curriculum details are arranged centrally for the benefit of external examinations. In both territories, the Australian Capital Territory (ACT) and the Northern Territory, schools have relatively broader autonomy. They can develop their curricula based on general objectives that have been determined at the school level. There are variations in the responsibility for curriculum development in each state, so there are differences in implementation. Suppose the curriculum is prepared based on guidelines and subject matter from the center. In that case, senior officials from the center regularly visit schools to monitor the curriculum's implementation, among others.

There is a test for students in Australia that applies nationally; Australia organizes NAPLAN (National Assessment Program-Literacy and Numeracy and requiring students to take tests. The intended students are students in grades 3, 5, 7, and 9. The test materials include reading, writing, language (spelling, grammar, and punctuation), and calculations. Each school also carries out exams, but these exams do not affect whether they advance to the next grade/stage. Because of the increase in the class automatically adjusts the age of students. Almost all preschool and primary education teachers and most secondary school teachers are educated at CAE (Colleges of Advanced Education). Several secondary school teachers and some basic education teachers received a university education. All school systems provide opportunities for teachers to receive in-service education, including upgrading of qualifications or diplomas by completing approved courses in advance. Teachers in Australia are equipped with knowledge and materials. Teachers' teaching license is obtained from the ministry of education in Australia. From Kindergarten teachers to senior high school teachers, the existing teachers have a high desire to develop themselves continuously. This sentiment also applies to teachers who are in remote areas or outskirt areas.

\section{Indonesian Education System}

In the 2003 National Education System Law, the function of the national education system is to develop abilities, shape character, educate the nation, develop student potential, become human beings who obey God Almighty, have noble morals, have broad insight, are capable, creative, independent, and a responsible human being. Based on the National Education System Law No. 20 of 2003, there are three education levels in Indonesia: First, Basic education. This education is the initial education for the first nine years of children's schooling, namely in Elementary School and Junior High School (JHS). At the end of the elementary education period, students must take and pass the National Examination to continue their education to JHS with three years of education. Basic education is defined as the most basic education and becomes the path to the next education. Second, further education is defined as continuing basic education and has two types (junior high school and senior high school). Third, higher education is the level of education after students' complete general/vocational secondary education. At the higher education level, it starts from diploma, bachelor, master, to doctor.

Based on Article 36 of the National Education System Law, the education curriculum in Indonesia consists of curriculum development concerning national education standards; curricula at each level of education are developed from the principles of educational units, curricula are compiled regarding the framework of a unitary state. Curriculum standards must have a broad context and match the character of each level of education. 
From the beginning of independence until the 70 s, Indonesia used the concept of state testing. In the '80s, it was turned into a school exam. Furthermore, in the $90 \mathrm{~s}$, the concept of state exams and school examinations were combined into National Final Stage Learning Evaluation. Finally, the policy becomes the Final School Examination (FSE) for elementary school, Junior high school, Senior high school, and equivalent. This is based on Article 58 of the fingerprint Law as follows: assessment of student learning outcomes and products by teachers, monitoring of student processes and progress during learning, assessment of educational institutions, independent and reasoned assessment of educational programs, and ongoing teacher and student assessments.

The law on the national education system in article 42 explains: (a) educators are required to have certification according to teaching hours, are physically and mentally healthy, and able to realize the goals of national education, and educators have standardized educational qualifications. Meanwhile, Government Regulation Number 19 of 2005 concerning National Education standards, in article 28, contains provisions that educators must have appropriate educational qualifications, be physically and mentally healthy, have national insight, have the expertise as evidenced by a certificate from the Educational Personnel Education Institute (EPEI). The type of teacher education is Teacher Professional Education (PPG) organized by the LPTK with academic qualifications: (1) Educators at the minimum basic education level of D-IV or S1 basic education, (2) Secondary education minimum D-IV or S1 secondary education, and (3) At the higher education level, educators have a minimum of S1 for Diploma programs, S2 for undergraduate programs, and S3 for Masters or Doctorate programs.

\section{Differences Indonesian and Australian Education Systems}

As we know, every country certainly has its policies in the education system it adheres to, likewise with Indonesia and Australia. It turns out that there are many comparisons between the education systems in Indonesia and Australia, not only from the level of education. The differences between Indonesian and Australian Education Systems are presented in Table 3.

Table 3. The differences between Indonesian and Australian Education Systems

\begin{tabular}{|c|c|c|c|}
\hline \multirow[b]{2}{*}{ Number } & \multicolumn{2}{|c|}{ Australia } & \multirow[b]{2}{*}{ Indonesia } \\
\hline & $\begin{array}{c}\text { New South } \\
\text { Wales, Victoria, } \\
\text { Tasmania, Australian } \\
\text { Capital Territory }\end{array}$ & $\begin{array}{c}\text { Queensland, Australia } \\
\text { Selatan, Australia } \\
\text { Barat, Northern } \\
\text { Territory }\end{array}$ & \\
\hline 1 & $\begin{array}{l}\text { Primary School ( } 6 \\
\text { years) } \\
\text { Junior Secondary } \\
\text { School ( } 4 \text { years) }\end{array}$ & $\begin{array}{l}\text { Primary School (7 years) } \\
\text { Junior Secondary } \\
\text { School (3 years) }\end{array}$ & $\begin{array}{l}9 \text { years of basic education } \\
\text { (SD } 6 \text { years and SMP } 3 \\
\text { years }\end{array}$ \\
\hline 2. & $\begin{array}{l}\text { Senior High School (2 } \\
\text { years) }\end{array}$ & $\begin{array}{l}\text { Senior High School ( } 2 \\
\text { years) }\end{array}$ & $\begin{array}{l}3 \text { years of secondary } \\
\text { education (SMA, MA, SMK, } \\
\text { and MAK) }\end{array}$ \\
\hline 3. & \multicolumn{2}{|c|}{$\begin{array}{l}\text { Diploma ( } 1 \text { year) } \\
\text { Associate degree, advanced diploma ( } 1.5 \text { years) } \\
\text { Bachelor degree (Bachelor Degree) ( } 3 \text { years) } \\
\text { Graduate certificate ( } 6 \text { months) } \\
\text { Graduate Diploma ( } 1 \text { year) } \\
\text { Masters / Master's Degree (1-3 years) } \\
\text { Doctorate ( } 3+\text { years) }\end{array}$} & $\begin{array}{l}\text { An Associate Expert, } \\
\text { Diploma } 3 \text { (D3) } \\
\text { Bachelor, Diploma } 4 \text { (D4) } \\
\text { Bachelor, Undergraduate } \\
\text { (S1) } \\
\text { Masters, Strata } 2 \text { (S2) } \\
\text { Doctor, Strata } 3 \text { (S3) }\end{array}$ \\
\hline
\end{tabular}

Apart from the level of education, several comparisons of existing education in Australia and Indonesia include: First, when viewed from the weight and level of difficulty of the teaching materials, the standard of basic education in Indonesia is higher than that of Australia. Second graders in primary school have received lessons on more than four subjects, a variety of 
complex homework, and tests. Meanwhile, first and second graders in Australia are not required to learn how to read. Second, giving awards or rewards is quite interesting. Primary school students in Australia who do good and have positive courage will be rewarded with a certificate, which is collected will be announced at the assembly, which is a bi-weekly event for the development of students' talents and arts. The school award and a report card also write the achievements or achievements that students have made. It can be seen here that character development and emotional intelligence are highly emphasized in basic education. Therefore, student report card assessments in Australia are narratives, not numbers like those found in schools in Indonesia.

Third, the learning climate in Australia (primary schools) feels more conducive than in Indonesia. The number of students is 20 students. The class has been equipped with media, portfolios, media, props, and student work. Fourth, in terms of teaching staff, teachers in Australia are much disciplined. Teachers are required to come to class before students enter. This seems to be being intensified in Indonesia. The morning briefing for teachers before entering the classroom is undoubtedly very good for increasing discipline for the teaching staff and discussing problems in the teaching and learning process. Fifth, it is different from schools in Indonesia, which at each level have a religious education. In Australia, religious education is not an obligation to be taken by the students in all schooling grades. Australia is a multicultural country where students have different religions. Students have the choice to study in private schools that usually offer religious education in their faiths, such as Catholic and Islamic private schools.

\section{The Comparison of the Basic Education Curriculum in Indonesia and Australia}

There are three levels of Government in Australia, namely Commonwealth or national Government; six states and two local governments; and many local governments. Responsibility for primary and secondary school education rests with the state or local government and includes curriculum preparation. The national curriculum in Australia was approved by the Australian Curriculum, Assessment and Reporting Authority (ACARA; Australian Authority for Curriculum, Assessment, and Reporting) in 2008. The ACARA function is to have content and curriculum achievement standards and to work following the directions of the Melbourne Declaration.

Philosophically, "The Australian Curriculum is designed to develop successful students, confident and creative individuals, and active and knowledgeable citizens". The Australian curriculum's philosophical foundation is stated in the ideals of the Melbourne Declaration. The Australian Curriculum structure applies equally to eight learning areas or subjects: English, Mathematics, Science, Health and Physical Education, Literature, Cultural Arts, Technology, and Foreign Languages. The document structure is the same for Foundation to Class X; the curriculum structure is different for Class XI and XII. Catholic schools and other independent schools with established religious principles may include religious studies and worship at school events. The Foundation-Class X curriculum is developed in subject knowledge, skills and understanding; general skills; and inter-curricular priorities. First, the general ability is a group that integrates and inter-connections knowledge, skills, behavior, and character that is used among all subjects, namely literacy, numeration, information, and communication technology skills, critical thinking, creative thinking, adaptability, social skills; ethical understanding, and understanding between cultures. Second, the three priorities for curriculum development are emphasized on learning the culture and history of Australia's indigenous people, the relationship and sustainability of Asia and Australia. Third, the standard for achieving the content of the curriculum is an important part of the subjects in the curriculum. Fourth, classroom learning should describe student activities as a standard of achievement for graduation. The development of a learning program becomes the focus of student learning. Teachers are allowed to assess student achievement and supervise teaching activities. Fifth, the content description describes the content taught by the teacher and learned by students. Content descriptions include knowledge, understanding, and skills for each grade level. There is also an elaboration of selected content for teachers to decide which content to teach. 
The Curriculum Framework in Australia was prepared to welcome the arrival of the XXI Century, with the slogan "Educating our Children to succeed in the 21st Century". Prof. Lesley Parker, Chair of the Curriculum Council, expressed pride, because "The Curriculum Framework was developed through a unique consultative process that involved almost 10,000 teachers, parents, academics, curriculum officers, students and other members of the community". In other words, curriculum development in Australia has involved all education stakeholders. There are several interesting points in the Curriculum Framework. First, there are eight basic conditions for curriculum development in Australia: cultural diversity, family structure, technology, environment, economy, and standard of living. Second, after the existence of the curriculum, there are five value characteristics, including knowledge, commitment, self-acceptance, self-esteem, caring attitude, social responsibility, and environmental responsibility.

In the National Educator Standard (Article 1 paragraph 15), the 2006 curriculum is explained. This curriculum is more operational than the previous curriculum and is arranged separately from each unit of educational institutions. The 2006 curriculum has taken into account the basic competencies proclaimed by the education supervisor. The preparation of the 2006 curriculum is also based on Law Number 20 of 2003 concerning the National Education System article 36 paragraphs 1 and 2, namely: (1) Curriculum development refers to the National Education Standards which embody the National Education Goals and (2) The curriculum at each level of education is extended from the existence of educational principles and has been verified in line with local wisdom in the area of the education unit, and is generalized with the potential of students as a whole (Asri, 2017).

The curriculum is divided into three levels, namely Elementary School (Class I-VI), Junior High School (Class VII-IX), and Senior High School (Class X-XII). The tier structure is similar. The structure is described in the 2013 Curriculum Documents as well as the Basic Competencies for each level. At primary school and vocational high school, subjects are grouped into two, and all subjects are compulsory, and subjects for primary school and vocational high school are shown as follows in Table 2. Besides, non-academic activities also support the implementation of the curriculum in Indonesia. The types are very diverse such as scouting, arts, martial arts, and the like (which are required for Senior High School), Interschool Student Organizations, School Health Units, and the Youth Red Cross.

According to the curriculum for Elementary Schools, Natural Sciences and Social Sciences are not taught like separate subjects: the content is "integrated into subjects civic education, Indonesian Language and Mathematics which must exist under statutory provisions". Thus, the government establishes a scientific approach as a thematic learning approach to process two competencies at once. The Ministry of Education and Culture writes that the primary school curriculum is divided into several subjects, namely: Natural Sciences, Social Sciences, civic education, Indonesian Language, and Mathematics. Meanwhile, the junior high school level curriculum contains the structure, teaching load, and organization of essential competencies in each subject matter. The subject group is divided into two at the high school level, namely the compulsory group (science and social) and the specialization group (Mathematics, Biology, Physics, and Chemistry).

\section{Discussion}

The results showed that there were many differences in terms of the education system, education policy, and the curriculum applied between Indonesia and Australia. The national education system is an important aspect that is often defined by the government as a way to educate and shape the character of the nation's children (Sasongko, 2018). When viewed from the education system, information is obtained that the education system in Australia has a policy of compulsory education for 10 at the primary and secondary school levels. Meanwhile, the education system in Indonesia has switched from being 9 years old, now the government has made it compulsory for children to study for 12 years. This education system is a followup to Law Number 20 of 2003 which contains compulsory education programs for the nation's children. Until now, the central government has instructed the ranks of the education government under it to socialize plans for the aging of the compulsory education program to a 
high school level or the equivalent of 12 years (Komar, 2017; Merlion, 2017). The 12-year study obligation has been echoed since 2015 , to be precise in June, together with the provision of an education budget from the Ministry of Finance in the State Expenditure Budget of 7.9 billion specifically for the 12-year compulsory education program (Shabana, 2016). This socialization must be accompanied by school services and facilities that support learning. Compulsory education is intended to defend the right to access and government education for children without exception (Jin \& Zhang, 2008; Seel, 2012). Unfortunately, during the implementation of the 12-year compulsory education, the government faced various obstacles, such as low parental participation in their children's education in the future, inadequate socialization to all regions, and poorly targeted education subsidies from the government to the community (Hasanah et al., 2017).

Apart from the 12-year study obligation, aspects of the examination system between Indonesia and Australia are also different. In Australia, they use the NAPLAN test. This test focuses on assessment, literacy, and numeracy programs. The standards applied are in the form of assessments of reading, writing, and counting. It is administered directly by ACARA and overseen by the education board in the Australian Government. This test is specifically for students in grades 3,5,7, and 9 to show the results of student performance during school (Wu, 2015). Previous findings reported that the results of the NAPLAN test were successful in significantly improving children's abilities (Smith, 2016). Meanwhile, Indonesia conducts the National Examination as a standard for testing students at each level. A national exam is a form of educational evaluation where educational evaluation is a major component of the education plan. Currently, Indonesia has created a breakthrough regarding the implementation of the Computer-based National examination system (Hidayatullah, Marzuki, \& Hakim, 2020). The implementation of the national exam is one of the goals to make it easier for students to continue their education to the next level and improve the quality of Indonesian education (Fanani \& Kurniawan, 2017; Iriani \& Manongga, 2018). Each student will take a national final exam so that students can continue to pursue secondary education (Alhamuddin, 2017). National examinations have played an active role in developing better education in Indonesia. The findings of this study support previous findings that implementing national exams at all levels of education is a way to improve the quality of outputs and assess educator competencies (Nursyam, 2017). This is demonstrated by the achievement of the examination's implementation in accordance with the original purpose of education, despite the fact that the test's implementation is hampered by a lack of facilities and infrastructure.

Another difference regarding the education system is also in terms of the difficulty level of the material, assessment, teaching staff and education, curriculum, and subjects. As shown in table 3, education qualifications in Australia must at least have a master's degree, while someone with a bachelor's degree can already become a teacher in schools in Indonesia. The standard of educators and teaching staff in every country is undergoing a constant dynamic process. Teachers are not only required to be able to teach but teachers have been verified based on the administration that they must fulfill (Wahyudi, 2010). Teachers must also have the skills and capacity to make breakthroughs, analyze issues that occur in the environment, provide solutions to problems, convey ideas, plan, organize programs, and be able to work together (Fauth et al., 2019; König, Jäger-Biela, \& Glutsch, 2020). Skills that need to be possessed include an understanding of work, work environment, career, career support, adaptation, technology, and community empowerment (Fuertes-Camacho, Graell-Martín, Fuentes-Loss, \& Balaguer-Fàbregas, 2019). Apart from being viewed by the teacher, the education system is said to be successful if the curriculum development standards contain a system regarding the linking of solving issues or problems by integrating the content of these problems (Schultz, Young, Gunning, \& Harvey, 2021). This means that two things are done directly theoretically and practically. This study's findings are similar to previous ones. According to Lase (2016), the education system in Australia is more flexible, whereas the education system in Indonesia focuses on behavior.

The world of education always synergizes with other components or fields so that educational goals can be achieved easily. Every field has an important and fundamental contribution, the curriculum is no exception. So, it can be said that the main pillar of teaching 
is the curriculum. Some experts say that the curriculum is the heart of education, success or failure, good and bad education originates and is determined by the curriculum. The curriculum is defined as a set of subjects, educational programs, and learning designs given to students. The curriculum in Indonesia is defined as a set of educational plans to keep up with society's dynamic demands (Wicaksono \& Sayekti, 2020). The national curriculum is designed based on Pancasila and the 1945 Constitution. The main objective of education is the difference between curricula in Australia and Indonesia. The difference between the 2013 curriculum and the previous curriculum is the development of the syllabus submitted by each education unit and the development of subject matter specifically from each school (Wahyuni, 2016). The syllabus already exists and is available from the center, but teachers in every educational institution need to improve their teaching plans as operational learning.

Talking about the curriculum cannot be separated from the educational institutions that implement the curriculum itself. The history of education in Indonesia itself started long before Indonesia's independence, which was carried out by institutions of Islamic boarding school education. Then after this nation became independent, Indonesia has self-managed schools since before the independence of the system the school was controlled by the colonizers. The history of education in Indonesia continues to undergo a long transformation to the present point (Soleman, 2020). There is a need to review the curriculum, and changes have to be made to improve the curriculum. This change is also caused by the dissatisfaction of society with the results of Indonesian education. If we look closely, it is not good to only compile a curriculum that is applied throughout the ages. So, surely the curriculum has developed and changed society to adapt to the times. This cannot be separated from the logical consequences of the development and improvement of the political situation, social conditions, the existence of culture, economic conditions, and the development of science and technology in the community.

Now, the curriculum used is the 2013 curriculum. This curriculum is the latest curriculum that was implemented in 1999 new teaching 2013-3014. Through the development of the 2013 curriculum, the government has high hopes that teachers will be able to produce students to be more powerful, proactive, productive, full mentality, skillful, integrity, and broadminded (Nova, Pratidina, \& Syarif, 2017). On the other hand, the elements of changes in the 2013 curriculum lie in graduate standards, teaching process and content, and evaluation/assessment. The qualification of graduates from the 2013 curriculum is at least able to balance fine motor skills with gross motor skills, practical skills, communication, character, and intellectual intelligence (Insani, 2019). Competence which was originally derived from subjects turned into subjects developed from competence.

The curriculum policy is the next finding that explains the similarity with this research. Curriculum policies are directly regulated by laws in each country (Wahyudin \& Suwirta, 2020). Curriculum policies are also developed in response to the country's demands and developments. This is consistent with the education curriculum should be in accordance with the times, which are based on dynamic rather than static life, in order to achieve the main purpose of education, namely humanizing people (Ilham, 2019). Both Indonesia and Australia integrate several subjects in their classrooms. This finding is consistent with the research, which found that the education systems in Indonesia and Australia integrate various lesson content from elementary school to high school (Michael, 2017). This system is still being refined.

Based on the above discussion, it can be concluded that the education systems in Indonesia and Australia have several differences and similarities. For example, differences exist in the assessment system, teaching methods, curriculum, syllabus, lesson plans, educational qualifications, and educational evaluations. The similarities between the two countries are that both countries experience a dynamic education system. The government in Indonesia and Australia continues to make improvements. This is also done to improve the quality and quantity of education in the country.

Overall, the findings of this study pertain to the educational systems of two countries (Indonesia and Australia). Several structured and programmed systems have been developed in both countries. Learning assessment and evaluation systems, learning 
methods/models/approaches/media, curricular policies, syllabus rules, and so on are all examined and applied on a regular basis, educators' abilities, as well as the appraisal of education in general. The difference between the two countries may be seen in the way things are done, such as in the way exams are administered. In Indonesia, the national exam is used, but in Australia, the NAPLAN test is used. The local government continues to manage and regulate both sorts of testing.

\section{Conclusions and Suggestions}

Education system in Australia is different from Indonesia in terms of compulsory education policies, teacher education qualifications, learning approaches, assessment, learning atmosphere, number of teaching staff, learning evaluation, and education curriculum. Indonesia applies the 2013 curriculum which contains education, culture and religion, while education in Australia does not mix culture or religion in the education curriculum. The findings of this study can serve as a guide for the government of education to be able to evaluate the education system, both the curriculum and its assessment. With a comparison of two different countries, each educator can assess the extent to which the education system lacks or strengths in his country. These findings can also be a reference for people to be more selective in choosing and determining the right education for their own families. Thus, parents are not wrong in choosing the appropriate education for their children and it is the first step towards realizing the success of education in their respective countries. From these conclusions and implications, the researchers suggest that educators expand their knowledge about education and curriculum. In addition, the researcher also advised the government to make these findings material for curriculum development in Indonesia. Furthermore, further literature researchers regarding the comparison of several developed countries need to be reviewed by future researchers to enrich the scientific knowledge of the education system and curriculum in each various countries.

\section{References}

Adha, M. A., Gordisona, S., Ulfatin, N., \& Supriyanto, A. (2019). Analisis komparasi sistem pendidikan Indonesia dan Finlandia. Tadbir: Jurnal Studi Manajemen Pendidikan, 3(2), 145. https://doi.org/10.29240/jsmp.v3i2.1102.

Alhamuddin. (2017). Studi perbandingan kurikulum pendidikan dasar Negara Federasi Rusia dan Indonesia. AL MURABBI, 3(2), 2406-2775. Retrieved from http://ejournal.kopertais4.or.id/mataraman/index.php/murabbi/article/view/2586/1901.

Asri, M. (2017). Dinamika kurikulum di Indonesia. Modelling: Jurnal Program Studi PGMI, 4(2), 192-202.

Retrieved

from http://www.jurnal.stitnualhikmah.ac.id/index.php/modeling/article/view/128.

Australian Goverment. (2016). The Australian Education System. Australia: Diplomatic Academy.

Aziz, A. (2011). Curriculum Development in Indonesian Education. Madrasah: Jurnal Pendidikan Dan Pembelajaran Dasar, 3(2). https://doi.org/10.18860/jt.v0i0.1312.

Chalkiadaki, A. (2018). A systematic literature review of 21 st century skills and competencies inpPrimary education. International Journal of Instruction, 11(3), 1-16. https://doi.org/10.12973/iji.2018.1131a.

Charron, N., Givens, T., Luedtke, A., Arregui, J., Creighton, M., \& Connell, K. O. (2013). Human development report 2015 work for human development. Public Health, 27(6), 1-8. https://doi.org/10.1177/0956247815583253.

Fanani, A. K. N., \& Kurniawan, R. Y. (2017). Evaluasi kelayakan ujian nasional pada perkembangan pendidikan di Indonesia. Jurnal Pendidikan Ekonomi, 5(3), 1-5. https://doi.org/doi.org/10.26740/jupe.v5n3.p\%25p.

Fauth, B., Decristan, J., Decker, A. T., Buettner, G., Hardy, I., Klieme, E., \& Kunter, M. (2019). The effects of teacher competence on student outcomes in elementary science education: The mediating role of teaching quality. Teaching and Teacher Education, 
86, 102882. https://doi.org/10.1016/j.tate.2019.102882.

Fuertes-Camacho, M. T., Graell-Martín, M., Fuentes-Loss, M., \& Balaguer-Fàbregas, M. C. (2019). Integrating sustainability into higher education curricula through the project method, a global learning strategy. Sustainability (Switzerland), 11(3), 1-25. https://doi.org/10.3390/su11030767.

Hasanah, Y. M., Safruddin, C., Jabar, A., Pauh, T., Yogyakarta, U. N., Hasanah, Y. M., ... Yogyakarta, U. N. (2017). Evaluasi program wajib belajar 12 tahun pemerintah daerah Kota Yogyakarta. Jurnal Akuntabilitas Manajemen Pendidikan, 5(2), 228-239. Retrieved from http://journal.uny.ac.id/index.php/jamp.

Hidayatullah, S., Marzuki, I., \& Hakim, L. (2020). UNBK: Transformasi Sistem Evaluasi Standar Nasional Di Era Revolusi Industri 4.0. Tadarus Tarbawy, 2(1). Retrieved from http://jurnal.umt.ac.id/index.php/JKIP/article/view/2575.

Ilham, D. (2019). Menggagas pendidikan nilai dalam sistem pendidikan nasional. Didaktika: Jurnal Kependidikan, 8(3), 109-122. https://jurnaldidaktika.org/contents/article/view/73.

Insani, F. D. (2019). Sejarah perkembangan kurikulum di Indonesia sejak awal kemerdekaan hingga saat ini. As-Salam: Jurnal Studi Hukum Islam \& Pendidikan, 8(1), 43-64. https://doi.org/10.51226/assalam.v8i1.132.

Iriani, A., \& Manongga, D. (2018). Using soft systems methodology as an approach to evaluate cheating in the national examination. Journal of Theoretical and Applied Information Technology, 96(11), 3344-3355. Retrieved from https://www.jatit.org/volumes/Vol96No11/12Vol96No11.pdf

Jin, Y., \& Zhang, H. (2008). Research on the costs of running compulsory education standards: Comparison of compulsory education internationally. Internasional Education Studies, $1,108-111$.

Komar, O. (2017). Correlation between the qualification of non-formal education program with the graduates competence. Journal of Nonformal Education, 3(2), 110-116. https://doi.org/10.15294/jne.v3i2.10945.

König, J., Jäger-Biela, D. J., \& Glutsch, N. (2020). Adapting to online teaching during COVID19 school closure: teacher education and teacher competence effects among early career teachers in Germany. European Journal of Teacher Education, 43(4), 608-622. https://doi.org/10.1080/02619768.2020.1809650.

Lase, B. P. (2016). Pendidikan dan nilai-nilai Budaya: Perbandingan pendidikan antara Indonesia, Australia, USA, dan Jepang. Didaktik, 10(2), 1813-1824. https://ojs.ikipgunungsitoli.ac.id/index.php/dk/article/download/45/43/84.

Lasmawan, I. W., \& Budiarta, I. W. (2020). Vygotsky's zone of proximal development and the students' progress in learning (A heutagogcal bibliographical review). Jurnal Pendidikan Indonesia (JPI), 9(4), 545-552. https://doi.org/10.23887/jpiundiksha.v9i4.29915.

Merlion, M. I. (2017). Pelaksanaan program wajib belajar 12 tahun di Kota Pekanbaru. JOM FISIP, 4(1), 68-70. $\quad$ Retrieved from https://www.neliti.com/publications/186043/pelaksanaan-program-wajib-belajar-12tahun-di-kota-pekanbaru.

Michie, M. (2017). Comparing the Indonesian Kurikulum 2013 with the Australian curriculum: Focusing on science for junior secondary schools. International Education Journal, 16(2), 83-96. http://members.ozemail.com.au/ mmichie/michie17.pdf.

Michie, M. (2019). Perbandingan kurikulum 2013 Indonesia dengan kurikulum Australia dengan fokus pada IImu Pengetahuan Alam (IPA). Jurnal Penelitian Pendidikan, 19(2), 257-268. https://doi.org/10.17509/jpp.v19i2.19770.

Muth'im, A. (2014). Understanding and responding to the change of curriculum in the context of Indonesian education. American Journal of Educational Research, 2(11), 10941099. https://doi.org/10.12691/education-2-11-15.

Nova, M., Pratidina, S. D., \& Syarif, A. (2017). English teachers' perspectives: Peerassessment in the 2013 curriculum. Jurnal Pendidikan Indonesia (JPI), 6(2), 198-207. https://doi.org/10.23887/jpi-undiksha.v6i2.10386. 
Nursyam. (2017). Efektivitas pelaksanaan ujian nasional tingkat sekolah menengah atas negeri oleh dinas pendidikan dan pengajaran kota palu provinsi sulawesi tengah. $E$ Jurnal Katalogis, 5(9), 11-21. http://jurnal.untad.ac.id/jurnal/index.php/Katalogis/article/view/9707.

OECD. (2016). Program for international student assessment (PISA) Result from PISA 2015. Retrieved from https://www.oecd.org/pisa/PISA-2015-Indonesia.pdf.

Pfeffer, F. T. (2015). Equality and quality in education a comparative study of 19 countries. Social Science Research, 51(1), 350-368. https://doi.org/10.1016/j.ssresearch.2014.09.004.

Rahim, R., \& Malik, M. (2015). Measuring student perceptions to personal characters building in education: An Indonesian case in implementing new curriculum in high school. Procedia-Social and Behavioral Sciences, 211, 851-858. https://doi.org/10.1016/j.sbspro.2015.11.112.

Reynolds, D., Caldwell, B. J., Cruz, R. M., Miao, Z., Murillo, J., Mugendawala, H., \& Ramon, M. R. R. (2015). Comparative educational research. In The Routledge International Handbook of Educational Effectiveness and Improvement. https://doi.org/10.4324/9781315679488.

Sarica, G. N., \& Cavus, N. (2009). New trends in 21st Century English learning. Procedia Social and Behavioral Sciences, 1(1), 439-445. https://doi.org/10.1016/j.sbspro.2009.01.079.

Sarkadi, S., \& Alghozali, M. I. (2020). Teaching materials of thematic comics in the 2013 curriculum learning in basic bchools. JPI (Jurnal Pendidikan Indonesia), 9(4), 618-627. https://doi.org/10.23887/jpi-undiksha.v9i4.20908.

Sasongko, N. (2018). The implementation of national standards of education for school quality improvement facing the 21st century (Descriptive evaluative studies in various levels of schools in Bengkulu province of Indonesia). International Journal of Current Research in Life Sciences, 07(08), 2647-2651. http://www.journalijcrls.com/sites/default/files/issues-pdf/01660..pdf.

Schultz, M., Young, K., Gunning, T. K., \& Harvey, M. L. (2021). Defining and measuring authentic assessment: a case study in the context of tertiary science. Assessment \& Evaluation in Higher Education, 7, 1-18. https://doi.org/10.1080/02602938.2021.1887811.

Seel, N. M. (2012). Encyclopedia of the sciences of learning. New York: Springer.

Shabana, A. (2016). Text construction of indonesia newspapers toward a-12 year mandatory education issue. The 2nd International Multidisciplinary Conference 2016, (2), 461471. https://jurnal.umj.ac.id/index.php/IMC/article/download/1232/1108.

Silalahi, R., \& Yuwono, U. (2018). The sustainability of Pancasila in Indonesian education system. Research in Social Sciences and Technology, 3(2), 58-78. Retrieved from https://www.learntechlib.org/p/187525/.

Smith, A. (2016). Home-schooled kids perform better in NAPLAN: report. Sydney: Fairfax Media. https://www.smh.com.au/national/nsw/homeschooled-kids-perform-better-innaplan-report-20160204-gmlgu9.

Soleman, N. (2020). Dinamika perkembangan kurikulum di Indonesia. Foramadiahi: Jurnal Kajian Pendidikan Keislaman, 12(1), 1-14. Retrieved from http://journal.iainternate.ac.id/index.php/foramadiahi/article/download/228/215.

Sulistiyarini, D., \& Sabirin, F. (2020). 21st century literacy skill of information technology and computer education students. Jurnal Pendidikan Indonesia, 9(4), 576-585. https://doi.org/10.23887/jpi-undiksha.v9i4.24432.

van Laar, E., van Deursen, A. J. A. M., van Dijk, J. A. G. M., \& de Haan, J. (2017). The relation between 21st-century skills and digital skills: A systematic literature review. Computers in Human Behavior, 72, 577-588. https://doi.org/10.1016/j.chb.2017.03.010.

Wahyudi. (2010). Standar kompetensi profesional guru. Jurnal Pendidikan Sosiologi Dan Humaniora, 1(2), 107-119. https://jurnal.untan.ac.id/index.php/JPSH/article/view/385.

Wahyudin, D., \& Suwirta, A. (2020). Politics of curriculum in the educational system in Indonesia. Tawarikh, 11(April), 143-158. Retrieved from 
http://www.journals.mindamas.com/index.php/tawarikh/article/view/1307.

Wahyuni, S. (2016). Curriculum development in Indonesian context the historical perspectives and the implementation. Universum, 10(1), 73-82. https://doi.org/10.30762/universum.v10i1.225.

Wicaksono, A. G., \& Sayekti, I. C. (2020). Bagaimana perbandingan kurikulum 2013 dengan kurikulum Australia pada mata pelajaran IPA? Natural: Jurnal IImiah Pendidikan IPA, 7(1), 21. https://doi.org/10.30738/natural.v7i1.8117.

Wrahatnolo, T., \& Munoto. (2018). 21St centuries skill implication on educational system. IOP Conference Series: Materials Science and Engineering, 296(1), 1-8. https://doi.org/10.1088/1757-899X/296/1/012036.

Wu, M. (2015). "What national testing data can tell us". In Lingard, Bob; Thompson, Greg; Sellar, Sam (eds.) (Vol. 27). Australia: Routledge. https://www.academia.edu/40525166/Drawing_on_recent_research_evidence_and_s chool_experience_critically_discuss_an_issue_in_teaching_and_learning_of_relevan ce_to_your_own_phase_and_specific_curriculum_area. 